\title{
Respon Komunitas Pemuda Faiths Terhadap Kajian Khitobah Berbasis Materi Tauhid
}

\author{
Nala Sakinah ${ }^{*}$, Sitty Sumijati ${ }^{1}$, Encep Taufik Rahman ${ }^{1}$ \\ ${ }^{1}$ Jurusan Komunikasi dan Penyiaran Islam, Fakultas Dakwah dan Komunikasi, UIN Sunan \\ Gunung Djati, Bandung
}

*Email:nala.sakinah97@gmail.com

\begin{abstract}
ABSTRAK
Tujuan penelitian ini yaitu untuk mengetahui respon komunitas pemuda faiths terhadap kajian khitobah berbasis materi tauhid yang rutin dilaksanakan setiap hari minggu di Masjid Islamic Center Garut. Adapun aspek respon yang dituju yaitu perhatian, pengertian, dan penerimaan. Teori yang digunakan dalam penelitian ini adalah teori S-O-R (Stimulus-Organism-Respon), diambil dari teori sosiologi komunikasi yang dikemukakan oleh Onong Uchjana Effendi dalam buku "Ilmu, Teori dan Filsafat Komunikasi" (2003). Dalam teori ini, untuk mengetahui respon maka terdapat tiga variable yaitu stimulus (kajian khitobah berbasis materi tauhid) organism (perhatian, pengertian, dan penerimaan) dan respon (perubahan sikap atau feedback) terhadap kegiatan kajian tersebut. Metode penelitian yang digunakan adalah metode kuantitatif, dimana data yang diperoleh berupa angka kemudian menggunakan pendekatan deskriptif untuk mendeskripsikan dan menarik kesimpulan hasil data dari penelitian lapangan berupa wawancara, observasi dan penyebaran angket kepada 30 responden sebagai sampel. Hasil penelitian membuktikan bahwa perhatian komunitas pemuda faiths terhadap kajian khitoah berbasis materi tauhid sangat tinggi dengan perolehan rata-rata skor 4,32, pengertian komunitas pemuda faiths terhadap kajian khitobah berbasis materi tauhid sangat tinggi dengan perolehan rata-rata skor 4,49, dan penerimaan komunitas pemuda faiths terhadap kajian khitobah berbasis materi tauhid sangat tinggi dengan perolehan rata-rata skor 4,44 .
\end{abstract}

Kata Kunci: Respon; Khitobah; Komunitas.

\section{ABSTRACT}

The purpose of this research is to find out the community pemuda faiths response, towards the dakwah of khitobah based on taubid material which is routinely carried out at the Islamic 
Center Garut Mosque. As for the intended response aspect, namely attention, understanding, and acceptance. The theory used in this study is theory S-O-R (Stimulus-Organism-Response), taken from the theory sociology of communication put forward by Onong Uchjana Effendi in the book "Communication science, Theory and Philosopby" (2003). In the theory to find response three variabels, namely stimulus (study of khitobah based on taubid material), organism (attention, understanding, and acceptance) and response (change of attitude or feedback) on the dakwah activity. The research method used is a quantitative method, where the data obtained are in the form of numbers then use a descriptive approach to describe and draw conclusion from the result of field research in the from of interviews, observation and questionnaires to 30 respondents as samples. The results of the study prove that the attention of the pemuda faiths community to the dakwah of khitobah based on taubid material is very high with the average score 4,32, understanding pemuda faiths community to the dakwah of khitobah based on taubid material is very high with the average score 4,49, and acception pemuda faiths community to the dakwah of khitobah based on taubid material is very high with the average score 4,44.

Keywords: Response; Khitobah; Community.

\section{PENDAHULUAN}

Metode dakwah pada dasarnya berpijak pada dua aktivitas yaitu aktivitas bahasa lisan/tulisan (bi ahsan al-qawl / bi al-kitabah) dan aktivitas badan atau perbuatan (bi ahsan al-'amal). Dalam tataran lebih teknis aktivitas lisan dalam menyampaikan pesan dakwah dapat berupa metode ceramah, diskusi, debat, dialog, petuah, nasihat, wasiat ta'lim dan lain sebagainya, sedangkan badan dalam menyampaikan pesan dakwah dapat berupa aksi amal sholeh, tolong menolong, pemberdayaan sumber daya manusia, lingkungan, penataan organisasi atau lembaga-lembaga keislaman.

Khitobah merupakan salah satu aktivitas dakwah atau tabligh melalui media mimbar yang nampaknya menjadi salah satu metode paling popular ditengah masyarakat. Bagaimana tidak, khitobah sudah menjadi budaya dalam berbagai aktivitas di masyarakat, baik itu dalam hal keagamaan atau yang lainnya. Misalnya dalam kegiatan pengajian, mayoritas materi yang da'i sampaikan itu melalui ceramah, khutbah jum'at, tanya jawab, pidato dan lain-lain. Salah satu unsur dakwah adalah pesan, pesan dakwah atau bisa disebut juga maudu haruslah tentang ajaran islam, yang sesuai dengan Al-Qur'an dan ajaran nabi.

Materi atau pesan yang disampaikan pun harus sesuai kebutuhan mad'u dengan harapan apa yang disampaikan dapat diterima dan di amalkan sehingga adanya feedback atau respon dari mad'u.Adapun kegiatan khitobah yang dilaksanakan di Masjid Islamic Center diantaranya khutbah jum'at, dan kajiankajian rutin. Salah satunya yaitu kajian yang diadakan oleh komunitas Pemuda Faiths ini, materi yang disampaikan adalah ketauhidan. Materi tentang mengenal Allah, mendekatkan diri dan selalu bergantung pada Allah, memperkuat iman 
sebagai pondasi agama, dan materi-materi lainnya yang berhubungan dengan ketauhidan dengan harapan adanya respon berupa perubahan sikap sesuai dengan tujuan dakwah yaitu ke arah yang lebih baik dan di ridhai oleh Allah. Materi atau pesan tentang ketauhidan dipilih berdasarkan mad'u atau objek dakwah pada kajian ini dominan remaja. Karena masa remaja adalah masa transisi dalam proses pertumbuhan dan perkembangan seorang individu dalam keseluruhan hidupnya. Pada masa ini, seseorang akan mulai mencari jati dirinya, memenuhi keinginan dirinya, dan mencari peranan social. Jika remaja mengalami krisis identitas, maka dapat mendorong timbulnya berbagai perilaku dan sikap tertentu sebagai upaya untuk mencari dan menemukan identitas diri. Pada masa ini juga penanaman keimanan sangatlah diperlukan, untuk mencegah manusia terjerumus pada hal-hal yang dilarang agama.

Pembinaan aqidah, akhlak, ketauhidan memang harus dari sejak usia dini, tetapi pada masa remaja lah yang justru sangat diperlukan. Maka dari itu, salah satu upayanya yaitu adanya suatu kegiatan dakwah yang mampu menarik perhatian para remaja. Contoh sebuah gerakan dakwah yang sedang ramai pada saat ini adalah munculnya komunitas, atau sekelompok orang yang berkumpul dalam satu wadah untuk mengekspresikan berupa kegiatan atau berkarya dengan pola pikir atau satu tujuan yang sama. Bayak kita jumpai saat ini komunitaskomunitas yang bergerak di bidang social, bidang olahraga, bidang seni, bahkan komunitas yang bergerak di bidang dakwah. "Pemuda Faiths" adalah salah satu komunitas yang mempunyai visi dan misi di bidang dakwah, juga mempunyai motto yaitu "Pejuang Generasi Akhir Zaman" komunitas ini didirikan pada bulan Juni tahun 2017. Umurnya memang belum lama, tetapi komunitas ini mempunyai eksistensi tersendiri di daerah Garut.

Komunitas ini merupakan salah satu pelopor yang mengadakan kajian bagi remaja, dan mampu mengajak pemuda pemudi di Garut untuk saling mengingatkan atau mengajak pada "Amar Ma'ruf Nahyi Munkar". Latar belakang berdirinya komunitas Pemuda Faiths ini sendiri yaitu untuk menyelamatkan kemerosotan akhlak dan moral pemuda-pemudi yang semakin tidak ada batasan, mengingat pemuda-pemudi pada saat ini tumbuh di zaman modern yang mana segala sesuatu didapat dengan mudah, lalu dijadikan gaya hidup, baik itu hal yang positif maupun hal yang negative. Maka dari itu, bimbingan jasmani dan ruhani sangatlah diperlukan untuk menyeimbangi arus perkembagan zaman.

Komunitas Pemuda Faiths ini mempunyai tujuan dan prinsip bagaimana dakwah di kemas dalam bentuk kegiatan atau ajakan yang menarik, sehingga dapat diterima oleh kalangan pemuda-pemudi atau kalangan remaja pada saat ini. Salah satu kegiatan khitobahnya nya yaitu kajian rutin setiap hari Minggu yang diadakan di masjid Islamic Center Garut, awalnya kajian ini hanya diikuti oleh 
beberapa orang. Namun dengan tekad yang kuat untuk berdakwah, saat ini kajian tersebut diikuti oleh ratusan pemuda-pemudi dari berbagai kalangan. Salah satu strategi yang dipakai adalah ikut bergabung dan bekerja sama dengan beberapa komunitas yang mempunyai kegiatan aktif, seperti komunitas olahraga di berbagai bidang, komunitas band, remaja masjid, mahsiswa, komunitas motor, komunitas penerbit buku, komunitas Odoj, PPA dan yang lainnya. Selain itu, mengadakan kegiatan social seperti donor darah, pengumpulan donasi untuk kaum duafa, khitanan massal, juga dakwah goes to school, goes to kampus dan dakwah goes to Kampung, yaitu kegiatan dakwah yang diadakan di suatu daerah, bekerja sama dengan karang taruna dan tokoh masyarakat setempat. Karena dengan strategi tersebut kemudian mereka tertarik untuk mengikuti kajian, maupun kegiatan positif lainnya dengan harapan adanya perubahan baik dari segi akhlak, tauhid, dan semangat dalam berdakwah khususnya remaja atau pemudapemudi yang ada di daerah Garut, dan umumnya seluruh umat muslim di setiap penjuru daerah lainnya.

Dari latar belakang masalah tersebut dapat dirumuskan beberapa masalah dengan masalah: bagaimana perhatian komunitas pemuda faiths terhadap kajian khitobah berbasis materi tauhid? Bagaimana pengertian komunitas pemuda faiths terhadap kajian khitobah berbasis materi tauhid? Bagaimana penerimaan komunitas pemuda faiths terhadap kajian khitobah berbasis materi tauhid?

Metode yang digunakan yaitu kuantitatif dimana hasil-hasil penelitian dihimpun kemudian dianalisis menggunakan alat analisis statistic untuk menemukan hasil dan kesimpulan melalui hipotesis. Adapun pendekatan yang dipakai adalah metode deskriptif, yaitu untuk membuat gambaran dari hasil wawancara bersama founder dan pengurus komunitas pemuda faiths, pembagian angket kepada responden dan observasi secara langsung ke lapangan mengenai situasi, menguji hipotesis, dan memberikan makna dan implikasi dari suatu masalah penelitian.

\section{LANDASAN TEORITIS}

Teori yang dijadikan landasan dalam penelitian ini adalah teori S-O-R dari Hovland. Adapun teori Hovland tersebut sebagaimana dikutip oleh Onong Uchina Effendi dalam bukunya yang berjudul "Ilmu, Teori, dan Filsafat Komunikasi" (Onong Uchjana, 1993 : 254) Teori S-O-R merupakan singkatan dari Stimulus-Organism-Response, berasal dari teori psikologi kemudian menjadi teori komunikasi. Tidak mengherankan, karena objek material dari psikologi dan ilmu komunikasi sama yaitu manusia. Menurut teori ini, bahwa efek yang ditimbulkan adalah reaksi khusus terhadap stimulus khusus, sehingga seseorang dapat mengharapkan dan memperkirakan kesesuaian antara pesan dan reaksi komunikan. Adapun unsur-unsur dalam model ini adalah:
1) Pesan (Stimulus)
:S

Tabligh: Jurnal Komunikasi dan Penyiaran Islam Vol. 3 No. 3 (2018) 245-257 
2) Komunikan (Organisme) :O

3) Efek (Response) : : R

Kamus Besar Bahasa Indonesia menyebutkan bahwa respon adalah tanggapan, reaksi, jawaban, terhadap suatu gejala peristiwa yang terjadi (KBBI, 1996 : 838). Respon berarti umpan balik (feedback) yang memiliki peranan atau pengaruh yang besar dalam menentukan baik atau tidaknya komunikasi. Dengan adanya respon yang disampaikan oleh objek dakwah (mukhhotob) kepada subjek khitobah (khotib) atau dari komunikan kepada komunikator akan memperkecil kesalah pahaman dalam sebuah proses dakwah atau komunikasi. Sedangkan menurut Soenarjo, respon merupakan suatu kegiatan komunikasi yang menimbulkan pengaruh (efek) positif atau negatif terhadap komunikan berupa respon terhadap pesan yang di sampaikan komunikator (Soenarjo, 1983 : 25). Umpan balik atau respon memainkan peranan yang amat penting dalam komunikasi. Sebab ia menentukan berlanjutnya komunikasi atau berhentinya komunikasi yang dilancarkan oleh komunikator. Oleh karena itu, umpan balik bersifat positif dapat pula bersifat negative. umpan balik positif adalah tanggapan atau respon atau reaksi komunikan yang menyenangkan komunikator sehingga komunikasi berjalan lancar. Sebaliknya umpan balik negatife dapat diartikan sebagai tanggapan komunikan yang tidak menyenangkan komunikatornya sehingga komunikator enggan untuk melanjutkan komunikasinya (Onong, 2004 : 14). Prof. Dr. Mar'at dalam bukunya "Sikap manusia, perubahan serta pengukurannya, mengutip pendapat Hovland, Jeans da Kelley yang menyatakan bahwa dalam menelaah sikap yang baru, ada tiga variable penting yaitu yang pertama perhatian, kedua pengertian, dan yang ketiga penerimaan. Perhatian yaitu keaktifan jiwa yang diarahkan kepada sesuatu obyek, baik di dalam maupun diluar dirinya (Ahmadi, 1983 : 97). Penerimaan merupakan kemampuan untuk memperhatikan dan merespon stimulasi yang tepat. Adapun pemahaman atau pengertian adalah hasil berfikir, yang merupakan rangkuman sifat-sifat pokok dari suatu barang atau kenyataan yang dinyatakan dalam satu perkataan.

Manusia adalah makhluk individu yang tidak dapat melepaskan diri dari hubungan dengan manusia lain. Sebagai akibat dari hubungan yang terjadi diantara individu-individu (manusia) kemudian lahirlah kelompok-kelompok social (social group) yang dilandasi oleh kesamaan-kesamaan kepentingan bersama. Kelompok atau group adalah kumpulan dari individu dari individu yang berinteraksi satu sama lain, pada umumnya hanya untuk melakukan pekerjaan, untuk meningkatkan hubungan antarindividu atau bisa saja untuk keduanya. Sebuah kelompok suatu waktu dibedakan secara kolektif, sekumpulan orang yang memiliki kesamaan dalam aktivitas umum namun dengan arah interaksi terkecil. Jika dilihat dari kacamata sosiologi, komunitas termasuk pada kelompok social primer dimana komunitas merupakan kelompok yang 
didalamnya terjadi interaksi social yang anggotanya saling mengenal dekat dan berhubungan erat dalam kehidupan. Sedangkan menurut George Homan komunitas atau kelompok social primer merupakan sejumlah orang yang terdiri dari beberapa orang yang acapkali berkomunikasi dengan lainnya sehingga setiap orang mampu berkomunikasi secara langsung (bertatap muka) tanpa melalui perantara (A Yesmin, $2013: 219$ ).

Komunitas adalah sebuah kelompok social dari beberapa organisme yang berbagi lingkungan, umumnya memiliki ketertarikan dan habitat yang sama. Dalam komunitas manusia, individu-individu didalamnya dapat memilki maksud, kepercayaan, sumber daya, preferensi, kebutuhan resiko, dan sejumlah kondisi lain yang serupa. Komunitas berasal dari bahasa latin communitas yang berarti "kesamaan", kemudian dapat diturunkan dari communis yang berarti "sama, public". Kata community menurut Syahyuti adalah berasal dari bahasa latin, yaitu "cum" yang mengandung arti together (kebersamaan) dan "munus" yang bermakna the gift (memberi) antara satu sama lain. Menurut Iriantara mendefinisikan makna komunitas adalah "sekumpulan individu yang mendiami lokasi tertentu dan biasanya terkait dengan kepentingan yang sama".

Pengertian khitobah tidak terlepas dari pengertian dakwah, bahkan khitobah adalah bagian teknik dakwah. Secara bahasa ia merupakan salah satu yang mengandung makna percakapan, ceramah (retorika). Khitobah adalah suatu teknik atau metode dakwah yang banyak diwarnai ciri karakteristik bicara seorang da'I pada suatu aktiitas dakwahnya. Ditinjau dari prosesnya, khitobah adalah suatu proses komunikasi, dalam arti kata proses tersebut terlibat dua komponen manusia yang terdiri dari da'I sebagai komunikator, dan mad'u atau pendengar sebagai komunikan. Dengan demikian, tujuan dari komunikasi sifatnya umum, sedangkan tujuan dari khitobah sebagai salah satu bentuk dakwah adalah khusus, yakni mengharapkan adanya partisipasi dari pihak komunikan dan kemudian dapat bersikap dan berbuat sesuai dengan ajaran islam. Dilihat dari proses kegiatannya dalam meresponi suatu kegiatan khitobah, seorang khotib akan mendapatkan respons dari mukhotobnya apabila dalam memberikan pesan khitobahnya sejalan dengan keinginan mukhotob. Menurut Onong Uchjana, komunikator yang baik adalah mereka yang mampu secara langsung menerjemahkan pikiran dan perasaan komunikan.

Secara bahasa, tauhid dibentuk dari kata dasar wahada-yahidu-wahdatan, bermakna to make into one (membuat menjadi satu). Menurut istilah agama islam, tauhid ialah "Keyakinan tentang satu atau Esanya Tuhan". Dalam ensiklopedi lintas agama (Abujamin rohman : 684) dikatakan tauhid itu adalah kepercayaan mutlak bahwa Allah itu Esa. Sedangkan ilmu tauhid ialah ilmu yang khusus mempelajari tentang ke-esa-an Allah, tentang substansi-Nya, perbuatan-Nya, maupun tentang sifat-sifatNya. Maka dari itu, mempelajari tauhid adalah mempelajari caara bagaimana membebaskan keyakinan manusia dan 
perbuatannya dari perbudakan ( A Dimyati, 2016 : 43). Berikut adalah skema dari penyelesaian permasalahan dari teori yang diambil:

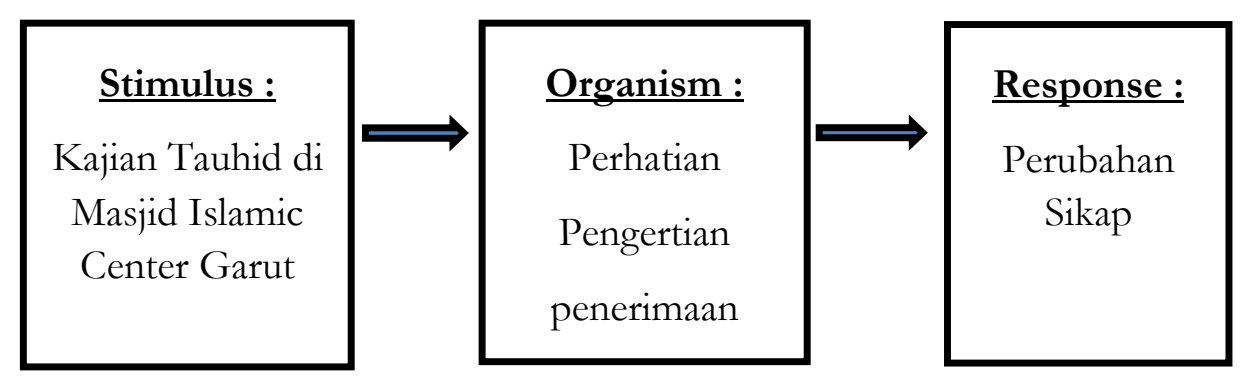

Respon dipengaruhi oleh beberapa unsurnya yaitu stimulus dan organism (proses yang terjadi pada individu). Maka dari itu, sebuah respon dalam kegiatan dakwah juga bisa dilihat dari skema diatas.

\section{HASIL DAN PEMBAHASAN}

Pada tahun 2016 para remaja dan pemuda pemudi menggagas sebuah gerakan komunitas markaz qur'ani, yang mana kegiatannya focus pada tahsin dan hafalan qur'an yang selanjutnya semakin berkembang hingga menjadi lembaga bernama Markaz Qur'ani (Rumah Tahfidz Cempaka). Seiring berjalannya waktu dan zaman yang canggih, maka tidak sedikit remaja yang terjerumus pada hal atau kegiatan negative yang akhirnya merusak moral dan akhlak. Beberapa orang dari anggota Markaz Qur'ani menggagas untuk mengadakan kegiatan positif berupa kajian yang dikemas secara menarik dengan tujuan untuk meminimalisir para remaja atau pemuda-pemudi terjerumus pada kegiatan yang negative. Dimulailah kegiatan kajian tersebut di Masjid Agung Tarogong, dan beberapa orang penggagas tersebut membentuk komunitas dengan nama "Pejuang Gaza" (Pejuang generasi akhir zaman). Dengan tekad yang kuat ingin berdakwah fokus komunitas ini adalah menyelenggarakan kegiatan kajian yang saling bersinergi agar semakin mempererat ukhuwah islamiyah khususnya generasi muda dan saling mendukung dalam proses hijrah diri maka kajian ini rutin dilaksanakan setiap hari Minggu dengan anggota yang semakin bertambah, Saat ini komunitas pemuda faiths memiliki secretariat yang beralamat di Jl. Otista Kp. Babakan Loa no 23, Garut.

Penelitian ini dilakukan di Masjid Islamic Center Garut terletak di Jl. Pramuka no 04, Pakuwon Kecamatan Garut kota Kabupaten Garut yang menjadi tempat dilaksanakannya kegiatan kajian setiap hari minggu pada pukul 14.00 sampai dengan selesai. Berdasarkan hasil wawacara bersama pengurus komunitas pemuda faiths, maka diperoleh data dan informasi mengenai visi dan misi komunitas pemuda faiths. Adapun untuk visi dari komunitas ini adalah 
"Menjadikan generasi muda agar lebih dapat berdaya guna dalam rangka mewujudkan pemuda yang berakhlakul karimah". Dan mempunyai misi diantaranya : pertama menggali, mengembangkan, dan memantapkan potensi dakwah, intelektual, dan sosial remaja. Kedua memposisikan Pemuda Faiths sebagai komunitas pemuda Islam mampu mewadahi remaja dalam proses hijrah diri. Dan yang ketiga mewujudkan amalan-amalan Islam dalam kehidupan pribadi, keluarga dan masyarakat.Adapun yang menjadi tujuan berdirinya komunitas pemuda faiths ini berdasarkan data yang diperoleh dari wawancara bersama pengurus komunitas pemuda faiths yaitu : pertama peningkatan kualitas pengetahuan dan pemahaman mengenai ilmu keislaman. Kedua untuk membangun karakter pemuda bangsa indonesia yg agamis. ketiga Mengkaji topik islami yg hangat di bicarakan. Dan yang keempat menjalin silaturrohim antar sesama muslim.

Perhatian Komunitas Pemuda Faiths Terhadap Kajian Khitobah Berbasis Materi Tauhid di Masjid Islamic Center Garut.

\begin{tabular}{lccccccc}
\hline $\begin{array}{l}\text { Pernyataan tentang } \\
\text { perhatian }\end{array}$ & SS & S & KS & TS & STS & Nilai & Mean \\
\hline $\begin{array}{l}\text { Menurut saya kegiatan } \\
\text { kajian ini merupakan } \\
\text { kegiatan yang positif. }\end{array}$ & 140 & 8 & - & - & - & 148 & 4,93 \\
$\begin{array}{l}\text { Metode penyampaian } \\
\text { yang digunakan da'I } \\
\text { tidak membosankan. }\end{array}$ & 20 & 92 & 6 & - & - & 118 & 3,93 \\
$\begin{array}{l}\text { Tema kajian yang } \\
\text { disampaikan menarik } \\
\text { perhatian saya. }\end{array}$ & 55 & 76 & - & - & - & 131 & 4,36 \\
$\begin{array}{l}\text { Gaya bahasa yang } \\
\text { digunakan da'I } \\
\text { menarik perhatian saya }\end{array}$ & 20 & 96 & 6 & - & - & 122 & 4,06 \\
$\begin{array}{l}\text { Menurut saya waktu } \\
\text { dan tempat kajian } \\
\text { sangat tepat }\end{array}$ & 60 & 64 & 6 & - & - & 130 & 4,33 \\
\hline & Jumlah & & & & & & \\
\hline
\end{tabular}

Dari tabel diatas, diketahui bahwa mean (rata-rata) skor perhatian anggota komunitas pemuda faiths terhadap kajian khitobah berbasisi materi tauhid di masjid Islamic Center Garut adalah 4,32. Berdasarkan kriteria analisis yang telah disebutkan pada terdahulu, sehingga dapat diketahui bahwa perhatian komunitas pemuda faiths terhadap kajian khitobah berbasis materi tauhid di Masjid Islamic 
Center Garut sangat tinggi. Dilihat dari hasil data yang dieproleh tidak terdapat responden yang memberikan perhatian negative terhadap kegiatan kajian tersebut.

\section{Pengertian Komunitas Pemuda Faiths Terhadap Kajian Khitobah Berbasis Materi} Tauhid di Masjid Islamic Center Garut.

\begin{tabular}{lccccccc}
\hline $\begin{array}{l}\text { Pernyatan tentang } \\
\text { pengertian }\end{array}$ & SS & S & KS & TS & STS & Nilai & Mean \\
\hline $\begin{array}{l}\text { Kajian ini membuat } \\
\text { saya lebih mengerti atau } \\
\text { faham ilmu yang belum } \\
\text { saya dapatkan. }\end{array}$ & 95 & 44 & - & - & - & 139 & 4,63 \\
$\begin{array}{l}\text { Materi tauhid dalam } \\
\text { kajian disampaikan }\end{array}$ & 50 & 80 & & & & & \\
dengan jelas. \\
$\begin{array}{l}\text { Pembahasan materinya } \\
\text { sesuai dengan ilmu } \\
\text { yang saya butuhkan. }\end{array}$ \\
$\begin{array}{l}\text { Kajian tauhid ini } \\
\text { mengingatkan saya } \\
\text { dalam memperbaiki } \\
\text { akhlak dan ibadah. }\end{array}$
\end{tabular}

Dari tabel diatas, diketahui bahwa mean (rata-rata) skor pengertian anggota komunitas pemuda faiths terhadap kajian khitobah berbasis materi tauhid di masjid Islamic Center Garut adalah 4,49. Berdasarkan kriteria analisis yang telah disebutkan pada bab terdahulu, sehingga dapat diketahui bahwa pengertian komunitas pemuda faiths terhadap kajian khitobah berbasis materi tauhid di Masjid Islamic Center Garut sangat tinggi. Tidak terdapat responden yang memberikan pengertian atau pemahaman negative terhadap kajian tersebut.

Penerimaan Komunitas Pemuda Faiths Terhadap Kajian Khitobah Berbasis Materi Tauhid di Masjid Islamic Center Garut.

\begin{tabular}{cccccccc}
\hline $\begin{array}{c}\text { Pernyataan tentang } \\
\text { penerimaan }\end{array}$ & SS & S & KS & TS & STS & Nilai & Mean \\
\hline
\end{tabular}


Nala Sakinah, Sitty Sumijati, Encep T Rahman

\begin{tabular}{|c|c|c|c|c|c|c|c|}
\hline $\begin{array}{l}\text { Kegiatan kajian ini } \\
\text { sangat bermanfaat } \\
\text { dalam beberapa hal } \\
\text { yang belum saya fahami } \\
\text { dan ketahui. }\end{array}$ & 85 & 52 & - & - & - & 137 & 4,56 \\
\hline $\begin{array}{l}\text { Pesan atau materi yang } \\
\text { disampaikan } \\
\text { mempengaruhi sikap } \\
\text { atau perilaku saya. }\end{array}$ & 85 & 52 & - & - & - & 137 & 4,56 \\
\hline $\begin{array}{l}\text { Tema kajian ketauhidan } \\
\text { yang disampaikan } \\
\text { sesuai harapan saya. }\end{array}$ & 25 & 96 & 3 & - & - & 124 & 4,13 \\
\hline $\begin{array}{l}\text { Saya merasa adanya } \\
\text { peningkatan } \\
\text { beribadah. }\end{array}$ & 75 & 56 & 3 & - & - & 134 & 4,46 \\
\hline $\begin{array}{lr}\text { Ilmu keagamaan saya } \\
\text { menjadi } & \text { bertambah } \\
\text { setelah } & \text { mengikuti } \\
\text { kajian. } & \end{array}$ & 85 & 48 & 3 & - & - & 136 & 4,53 \\
\hline \multicolumn{6}{|c|}{ Jumlah } & 668 & 22,24 \\
\hline
\end{tabular}

Dari tabel diatas, diketahui bahwa mean (rata-rata) skor penerimaan anggota komunitas pemuda faiths terhadap kajian khitobah berbasisi materi tauhid di masjid Islamic Center Garut adalah 4,44. Berdasarkan kriteria analisis yang telah disebutkan pada bab satu, sehingga dapat diketahui bahwa penerimaan komunitas pemuda faiths terhadap kajian khitobah berbasis materi tauhid di Masjid Islamic Center Garut sangat tinggi. Tidak terdapat responden yang memberikan penerimaan negative terhadap kajian tersebut.

\section{PENUTUP}

\section{Pertama Analisis Hasil Penelitian Perhatian Komunitas Pemuda Faiths Terhadap Kajian Khitobah Berbasis Materi Tauhid.}

Berdasarkan data dan hasil yang diperoleh, bahwa perhatian komunitas pemuda faiths terhadap kajian khitobah ini dengan skor 4,32 dan dilihat dari kriteria analisis menunjukan hasil sangat tinggi. Maka, jika dilihat dari aspek kajian teoritis salah satu unusur respon adalah perhatian yang merupakan salah satu aspek psikologis tertuju pada suatu objek yang datang dari dalam dan luar diri individu. Dalam ilmu komunikasi, respon merupakan efek atau feedback 
dari suatu rangsangan, baik itu efek negative maupun efek positif. Adapun factor-faktor yang mempengaruhi perhatian, diantaranya:

a) Gerakan, seperti organisme lain manusia tertarik pada objek-objek yang bergerak.

Adapun dalam angket dinyatakan dalam bentuk pernyataan "Metode penyampaian yang digunakan da'I tidak membosankan”. Metode yang dimaksud disini diantaranya cara penyampaian materi, melalui media. Contohnya menggunakan proyektor. Maka mukhotob akan lebih tertarik karena selain lebih jelas, materi kajian juga bisa dibagikan dalam bentuk file sehingga lebih efektif. Factor ini mampu menarik perhatian mukhotob yang dinyatakan dalam peolehan data hasil pengolahan angket yaitu 28 responden atau 93\% memilih sangat setuju, dan 2 responden atau 7\% memilih setuju.

b) Intensitas stimulasi. Kita akan memperhatikan stimulus yang lebih menonjol dari stimulus lainnya.

Untuk mengetahui perhatian responden terhadap factor ini, dalam angket dinyatakan dalam bentuk pernyataan "Gaya bahasa yang digunakan da'I menarik perhatian saya". Adapun alasan ditanyakannya hal tersebut kepada responden karena da'I atau penceramah dalam kajian tersebut terbilang masih muda. Sehingga cara penyampaiannya kata atau kalimat dikemas dalam bahasa yang ringan, jelas, lugas, dan sesekali menggunakan bahasa gaul, maka mudah difahami oleh mukhotob yang mayoritas remaja. Factor ini mampu menarik perhatian mukhotob, yang dinyatakan dalam bentuk perolehan data hasil pengolahan angket yaitu 4 responden atau 13\% menyatakan sangat setuju, 24 responden atau $80 \%$ menyatakan setuju, dan 2 responden atau $7 \%$ menyatakan kurang setuju.

c) Kabaruan. Hal-hal baru yang luar biasa yang berbeda akan menarik perhatian.

Dalam aspek ini, penulis ingin mengetahui sejauh mana hal-hal baru dalam kegiatan kajian setiap minggu ini bisa menarik perhatian responden. maka dituangkan dalam angket kepada responden dengan bentuk pernyataan "Tema kajian yang disampaikan menarik perhatian saya". Factor ini pun mampu menarik perhatian responden, dikerenakan tema setiap minggu berbeda dan dikemas secara menarik yang dinyatakan dalam bentuk perolehan data hasil pengolahan angket yaitu 11 responden atau 37\% menyatakan sangat setuju, dan 19 responden atau 63\% menyatakan setuju.

Dilihat dari hasil perolehan data, maka dapat dinyatakan bahwa perhatian responden terhadap kajian ini sangat tinggi dan tidak terdapat respon negative. Adapun aspek-aspek perhatian ini sebagai stimulus terhadap pemahaman yang diterima responden selanjutnya proses penerimaan yang mana akan 
menimbulkan efek. Maka pada aspek perhatian ini stimulus yang kuat sangat diperlukan sebagai rangsangan untuk mendapatkan pemahaman dan penerimaan responden sesuai harapan.

\section{Kedua, Analisis Hasil Penelitian Pengertian Komunitas Pemuda Faiths Terhadap Kajian Khitobah Berbasis Materi Tauhid.}

Stimulus atau rangsangan yang diberikan dan disampaikan kepada komunikan akan terjadi dua kemungkinan, yaitu diterima atau ditolak. Mengacu pada data hasil item 1 dimana unsur respon yaitu "perhatian" menunjukan hasil sangat tinggi oleh responden. Selanjutnya adalah proses mengerti atau pada unsur "pengertian" jawaban responden dalam bentuk pernyataan dalam angket yang berhubungan dengan aspek-aspek pengertian. Maka diperoleh hasil data pengolahan angket dengan skor 4,49 dan dilihat dari kriteria analisis menunjukan hasil sangat tinggi. Adapun factor-faktor yang mempengaruhi mengerti atau tidaknya mukhotob terhadap kegiatan kajian ini yaitu diantaranya tema atau materi kajian sesuai yang diharapkan dan kebutuhan mad'u, faham atau mengerti setiap materi kajian yang disampaikan sehingga adanya niat memperbaiki akhlak, dan metode penyampaian da'I sesuai dengan psikologis mukhotob sehingga lebih mudah untuk dimengerti.

\section{Ketiga, Analisis Hasil Penerimaan Perhatian Komunitas Pemuda Faiths Terhadap Kajian Khitobah Berbasis Materi Tauhid.}

Efek atau perubahan perilaku dalam teori S-O-R ini yaitu ketika stimulus atau rangsangan mendapat perhatian dari komunikan, lalu dimengrti atau difahami, maka selanjutnya yaitu penerimaan. Untuk mencapai keberhasilan adanya feed back atau efek, maka komunikator harus memberikan tambahan stimulus yang lebih kuat. Untuk mengetahui sejauh mana feed back mad'u terhadap kegiatan kajian ini, penulis menanyakan dalam angket aspek-aspek penerimaan dalam bentuk beberapa pernyataan. Setelah pengolahan data didapat hasil dengan skor 4,44, dan jika dilihat dari kriteria analisis menunjukan hasil sangat tinggi. Adapun efek dari kegiatan kajian ini terhadap para mad'u beberapa diantaranya yaitu:

a) "Pesan atau materi yang disampaikan mempengaruhi sikap atau perilaku saya" diperoleh jawaban 17 responden atau 57\% sangat setuju dan 13 responden atau $43 \%$ menyatakan setuju.

b) "Ilmu keagamaan saya menjadi bertambah setelah mengikuti kajian" diperoleh jawaban 17 responden atau 57\% menyatakan sangat setuju, 12 responden atau $12 \%$ menyatakan setuju dan 1 responden atau $3 \%$ menyatakan kurang setuju.

c) "Saya merasa adanya peningkatan dalam beribadah" diperoleh jawaban 15 responden atau 50\% menyatakan sangat setuju, 14 responden atau 
47\% menyatakan setuju, dan 1 responden atau 3\% menyatakan kurang setuju.

Jika dilihat pada aspek ini diperoleh efek kognitif dan efek afektif secara bersamaan. Efek kognitif terjadi bila ada perubahan pada apa yang diketahui, dipahami, atau dipersepsi khalayak. Dalam hal ini terdapat efek kognitf terhadap responden berdasarkan data yang diperoleh dalam bentuk pernyataan "Kegiatan kajian ini sangat bermanfaat dalam beberapa hal yang belum saya fahami dan ketahui" dengan jawaban 17 responden atau 57\% menyatakan sangat setuju dan 13 responden atau $43 \%$ menyatakan setuju adanya efek kognitif atau perubahan dalam beberapa hal yang belum diketahui dan difahami oleh responden. Adapun efek afektif timbul bila ada perubahan pada apa yang dirasakan, disenangi, atau dibenci khalayak (responden). Dalam hal ini terdapat efek afektif terhadap responden berdasarkan data yang diperoleh dalam bentuk pernyataan "Pesan atau materi yang disampaikan mempengaruhi sikap atau perilaku saya" dengan jawaban 17 responden atau 57\% menyatakan sangat setuju dan 13 responden atau $43 \%$ menyatakan setuju adanya efek afektif dalam perubahan perilaku dan sikap responden.

\section{DAFTAR PUSTAKA}

Ahmadi, Abu. (2009). Psikologi Umum, Jakarta: Rieka Cipta.

Anwar, Yesmin. (2013). Sosiologi Untuk Universitas. Bandung: Refika Aditama.

Dimyati, Ayat. (2016). Taubid Ilmu, Bandung: LAZISMU Mujahidin.

KBBI, 1996: 838

Soenarjo, (1983). Himpunan Istilah Komunikasi, Yogyakarta : Liberty (hl 25).

Effendi, U.O. (2004). Ilmu Komunikasi Teori dan Praktek. Bandung: Rosdakarya (hl 14)

Effendi, U.O. (2003). Ilmu, Teori dan Filsafat Komunikasi, Bandung: PT. Citra A Bakti. 